KONSTAN
JURNAL FISIKA DAN PENDIDIKAN FISIKA
Volume 6, Nomor 2, Desember 2021
$\begin{array}{r}\text { E-ISSN : 2460-9129 dan P-ISSN : 2460-9110 } \\ \text { http://jurnalkonstan.ac.id/index.php/jurnal }\end{array}$

\title{
Analisis Miskonsepsi Siswa SMA Negeri 04 Bombana Dengan Menggunakan CRI Pada Konsep Suhu dan Kalor
}

\author{
La Ode Asmin ${ }^{1, *)}$, Rosdianti $^{2}$ \\ ${ }^{1)}$ Program Studi Tadris Fisika, Institut Agama Islam Negeri (LAIN) Kendari, Jl. Sultan Qaimuddin, Kendari, \\ Sulawesi Tenggara \\ 2) Program Studi Tadris Fisika, Institut Agama Islam Negeri (LAIN) Kendari, Jl. Sultan Qaimuddin, Kendari, \\ Sulawesi Tenggara
}

*E-mail korespondensi: fisikakuanta@gmail.com

\begin{abstract}
Info Artikel: Abstract
Dikirim:

20 Agustus 2021

Revisi:

23 Agustus 2021

Diterima:

31 Desember 2021

Kata Kunci:

Salah satu penyebab siswa mengalami kesulitan belajar fisika adalah miskonsepsi. Miskonsepsi merupakan pemahaman konsep yang tidak sesuai dengan teori ilmiah. Tujuan dari penelitiana ini adalah mengidentifikasi miskonsepsi siswa menggunakan Certainty of Response Index (CRI) pada materi suhu dan kalor dengan metode deskriptif. Jumlah sampel dalam penelitian ini adalah 80 siswa SMA Negeri 04 Bombana. Intrumen tes yang digunakan adalah tes diagnostik pilihan ganda tiga tingkat atau three-tier test. Analisis data dilakukan dengan cara mencari persentase pemahaman siswa dan jawaban benar pada setiap item soal, serta persentase miskonsepsi untuk setiap item soal. Hasil penelitian menunjukkan rata-rata persentase jawaban benar siswa sebesar 35,15\%, rata-rata miskonsepsi $66,5 \%$, rata-rata CRI kategori tinggi sebesar 78,13\%, kategori rendah sebesar $21,19 \%$ dan tidak paham konsep sebesar 21,1\% pada materi suhu dan kalor. Rata-rata alasan jawaban benar siswa diperoleh $29,19 \%$ lebih rendah dari alasan jawaban salah yaitu $70,81 \%$. Hal ini mengindikasikan bahwa siswa dalam memilih jawaban tanpa didasari oleh pemahaman terhadap konsep fisika yang ada. Persentase miskonsepsi tertinggi terletak pada miskonsepsi item soal 1, 2, 5 dan 13 yaitu 63 siswa dengan persentase 79\% yaitu materi konsep "definisi suhu, sifat termometrik benda, penentuan titik didih air, dan perbandingan benda dalam menerima kalor".
\end{abstract}

(C) 2021 Universitas Islam Negeri Mataram

\section{PENDAHULUAN}

Belajar merupakan sustu proses membangun hubungan antara pengetahuan baru dan pengetahuan yang sudah ada sebelumnya. Dalam proses pembelajaran, siswa membangun pengetahuan baru melalui kerangka kognitif, kemampuan, nilai dan pengalaman mereka [1].Telah banyak dilakukan penelitian dalam pendidikan fisika tentang apa yang siswa ketahui dan bagaimana mereka belajar dan memahami konsep-konsep dasar dalam fisika.Kerangka konseptual semua anak berkembang dari pengalaman sehari-hari mereka, tetapi seringkali pemahaman intuitif tentang dunia di sekitar mereka tidak sesuai dengan penjelasan konsep ilmiah. Sebagian besar, konsep-konsep ini bertentangan dengan konsep fisika yang diterima secara ilmiah yang diajarkan di kelas fisika. Penting dalam merencanakan instruksi untuk mengetahui bagaimana konsepsi simplistis ini berbeda dari penjelasan ilmiah, dan mengapa anak-anak membangun ide-ide ini [2]. 
Miskonsepsi merupakan pemahaman konsep yang tidak sesuai dengan penjelasan ilmiah yang diterima oleh para ahli di bidang tersebut [3,4] atau keyakinan yang bertentangan dengan teori ilmiah yang diterima [5]. Siswa yang mengalami miskonsepsi pada suatu konsep dasar, maka peluang munculnya miskonsepsi semakin besar pada konsep yang lebih kompleks. Miskonsepsi dalam ruang lingkup Fisika tampaknya menjelaskan korelasi atau fenomena alam secara ilustratif, namun, hanya didasarkan pada pengamatan dan spekulasi sehari-hari. Siswa cenderung mempertahankan pemahaman konsep yang simplisits seperti materi energi dan gaya baik dari level sekolah hingga pada level memasuki perguruan tinggi [6].

Untuk memahami konsep-konsep Fisika, kendala utama yang dihadapi siswa adalah level representasi, makroskopik dan simbolik dari materi fisika yang hampir terjadi disemua bidang kajian fisika. Akibatnya siswa mengalami kesulitan untuk memahami konsep-konsep dalam fisika dengan tepat. Karena itu, siswa memiliki beragam pemahaman terhadap konsep fisika yang menyebabkan adanya kecenderungan penyimpangan atau ketidaksesuaian yang dikenal sebagai miskonsepsi.Kesalahpahaman dalam fisika memberikan penjelasan yang tampaknya benar untuk korelasi dan fenomena, tetapi sebenarnya tidak konsisten dengan eksperimen.Miskonsepsi siswa pada pembelajaran fisika hampir terjadi pada semua kajian bidang ilmu fisika. Hasil penelitian menunjukan bahwa siswa mengalami miskonsepsi 66,0\% pada materi tentang konsep hukum Newton [7], materi kinematika gerak lurus $32,50 \%$, usaha dan energi $51,82 \%$, impul, momentum dan tumbukan sebesar 48,61\% [8], miskonsepsi pada materi usaha, gaya dan energi terutama pada konsep tentang pengaruh gravitasi terhadap kecepatan benda yang bergerak jatuh bebas yaitu sebesar 84\% [9]. Dari beberapa hasil penelitian tersebut menunjukkan bahwa, siswa mengalami miskonsepsi pada hampir semua materi pada mata pelajaran fisika.

Sumber miskonsepsi seringkali adalah beberapa pengalaman praktis [10]. Siswa sudah memiliki beberapa kesalahpahaman sebelum memulai mempelajari fisika. Peran pengalaman yang dikumpulkan pada fase awal pendidikan fisika sangat dominan.Di sisi lain, pengetahuan awal yang tidak memadai, penalaran yang tidak lengkap, dan intuisi yang salah juga merupakan penyebab terjadinya miskonsepsi siswa [11].Selain bersumber dari siswa, kekeliruan dan kurangnya pemahaman tenaga pengajar dalam memberikan materi ajar, dapat menyebabkan terjadinya miskonsepsi pada siswa. Guru memiliki andil yang besar dalam membentuk konsepsi siswa nampaknya perlu mendapat perhatian.

Salah satu jenis instrumen untuk mengetahui miskosnepsi siswa adalah tes pilihan ganda dengan keunggulan lebih efisien dan mudah dalam melakukan analisis miskonsepsi. Ada beberapa tipe tes pilihan ganda yang telah dikembangkan diantaranya one tier, two-tiers dan three-tiers multiple choice $[12,13]$. Dalam penelitian ini, instrumen yang digunakan adalah three-tierskarena paling valid, reliabel, dan akurat serta dapat mengetahui secara mendalam dalam mengidentifikasi miskonsepsi yang terjadi pada siswa $[14,15]$.

Kesulitan peserta didik terkait konsep fisis dan matematis tersebut berakibat pada saat terjadi kesalahan-kesalahan dalam menyelesaikan soal ujian dan menjadi penyebab tidak tercapainya hasil belajar peserta didik secara optimal. Miskonsepsi pada peserta didik yang muncul secara terus menerus dapat mengganggu pembentukan konsepsi ilmiah. Pembelajaran yang tidak memperhatikan miskonsepsi menyebabkan kesulitan belajar dan akhirnya akan mengakibatkan rendahnya prestasi belajar peserta didik. Pada akhirnya, bila tidak segera diperbaiki miskonsepsi tersebut akan menjadi hambatan bagi peserta didik pada proses pembelajaran lanjut [16].

Karena itu, untuk mengatasi hambatan tersebut perlu dilakukan dengan menyertakan metode Certainty of Responses Index (CRI) pada pembuatan bentuk soal tes pilihan ganda. Tingkat pertama, kedua, dan ketiga masing-masingadalah pilihan jawaban dari soal pilihan ganda, alasan jawaban yang dipilih, dan skala CRI. Adanya CRI, untuk menidentifikasi siswa yang tahu konsep, miskonsepsi, dan tidak tahu konsep. Penelitian ini bertujuan untuk mengetahui besar persentase dan miskonsepsi siswa pada materi suhu dan kalor dengan menggunakan metode CRI. 


\section{METODE PENELITIAN}

Jenis penelitian ini adalah penelitian kualitatif dengan pendekatan kualitatif deskriptif yaitu suatu penelitian yang bermaksud memahami fenomena tentang apa yang dialami oleh subjek penelitian. Sampel dalam penelitian ini adalah peserta didik kelas XI MIA di SMA Negeri 04 Bombana Tahun Ajaran 2020/2021 yaitu sebanyak 80 siswa. Teknik pengambilan sampel yang dipakai dalam penelitian ini adalah teknik sampling jenuh.

Dalam penelitian ini, Instrumen yang digunakan adalah tes berupa tes diagnostik pilihan ganda tiga tingkat untuk mengetahui tingkat pemahaman peserta didik pada materi Suhu dan Kalor dan hasilnya dianalisis dengan menggunakan metode CRI.

Tabel 1. Kriteria Tingkat pemahaman konsep siswa [13]

\begin{tabular}{cccc}
\hline Tingkat Pertama & Tingkat Ke Dua & Tingkat Ke Tiga (CRI) & Kriteria \\
\hline Benar & Benar & Tinggi & Paham Konsep \\
Benar & Benar & Rendah & Tidak Paham Konsep \\
& Salah & & \\
Salah & Benar & & \\
& Salah & Tinggi & Miskonsepsi \\
Benar & Salah & & \\
Salah & Benar & & \\
& Salah & & \\
\hline
\end{tabular}

\section{HASIL DAN PEMBAHASAN}

Gambar 1 menunjukkan persentase pemahaman siswa yang terdiri atas paham konsep (PK), miskonsepsi (MIS), dan tidak paham konsep (TPK).

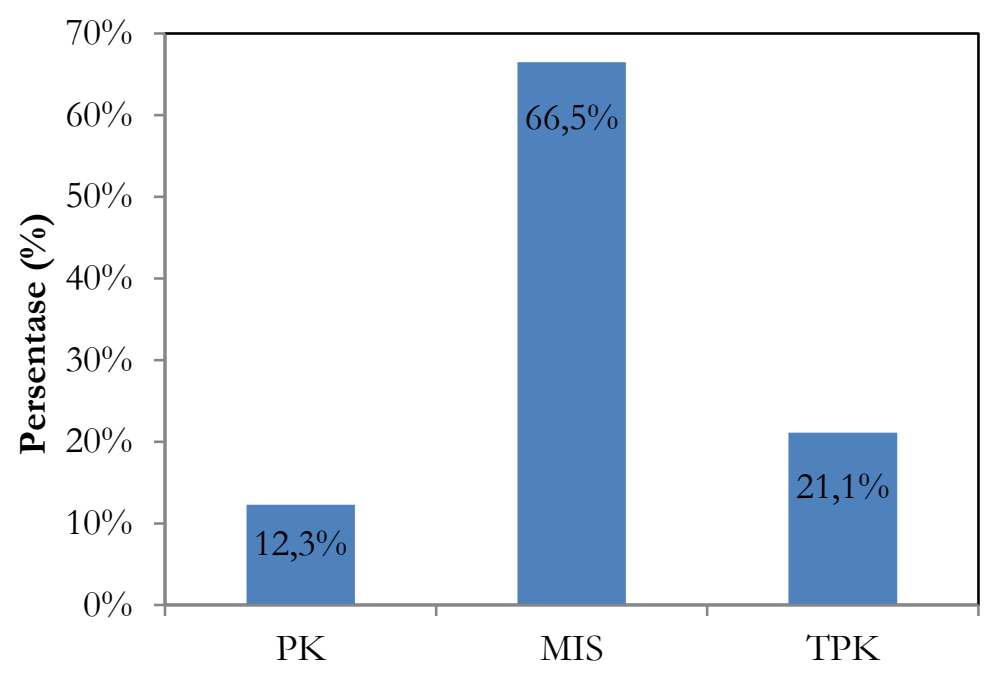

Gambar 1. Tingkat persentasi pemahaman siswa

Golongan paham konsep (PK) adalah peserta didik dapat memilih jawaban dengan benar dengan alasan jawaban benar serta CRI yang tinggi. Pada golongan miskonsepsi (MIS) maksudnya adalah peserta didik dapat memilih jawaban dengan benar/salah dengan alasan jawaban salah, benar, dan salah serta CRI yang tinggi. Kemudian untuk golongan tidak paham konsep (TPK) maksudnya adalah peserta didik dapat memilih jawaban dengan benar/salah dengan alasan jawaban benar/salah serta CRI yang rendah.Berdasarkan analisis CRI, diperoleh bahwa siswa yang mengalami paham konsep dengan persentase terendah 12,3\%, sedangkan persentase siswa yang tertinggi adalah miskonsepsi yaitu 66,5\%, dan siswa mengalami tidak paham konsep yaitu sebesar 21,1\%. 


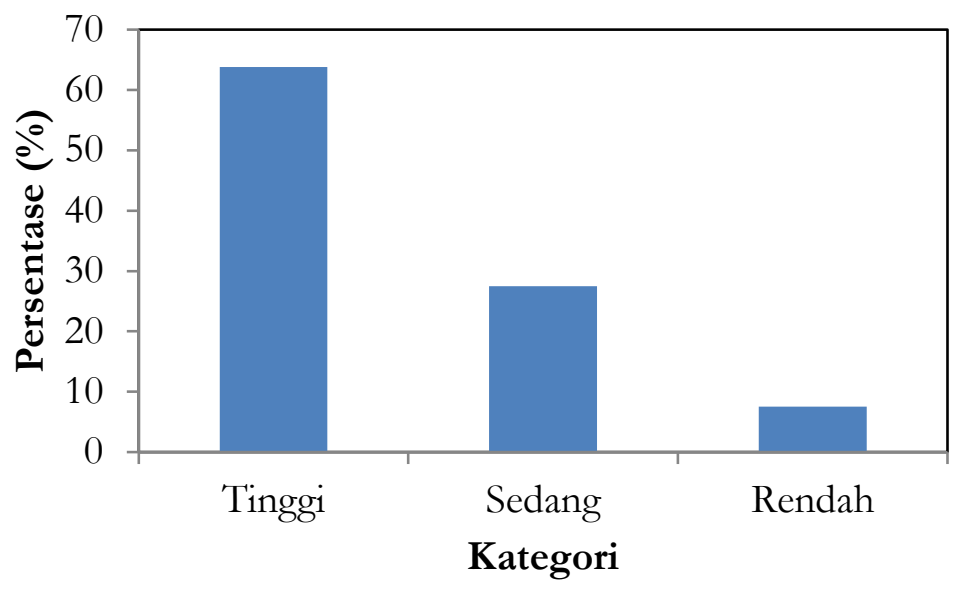

Gambar 2. Grafik Persentasi Kategori Miskonsepsi Siswa

Dari gambar 2, kategori miskonsepsi siswa dikategorikan kedalam tiga kategori yaitu miskonsepsi kategori terendah sebesar 7,5\%; miskonsepsi kategori sedang sebesar 27,5\%; dan miskonsepsi kategori tinggi sebesar 63,8\%. Hasil ini menunjukan bahwa siswa masih megalami kesulitan dalam mempelajari materi suhu dan kalor. Untuk melihat lebih jelas tentang konsep materi yang sulit dipahami oleh siswa, maka berdasarkan hasil analisis data, diperoleh gambaran miskonsepsi, paham konsep, dan tidak paham konsep siswa yaitu ditunjukan pada gambar 3 .

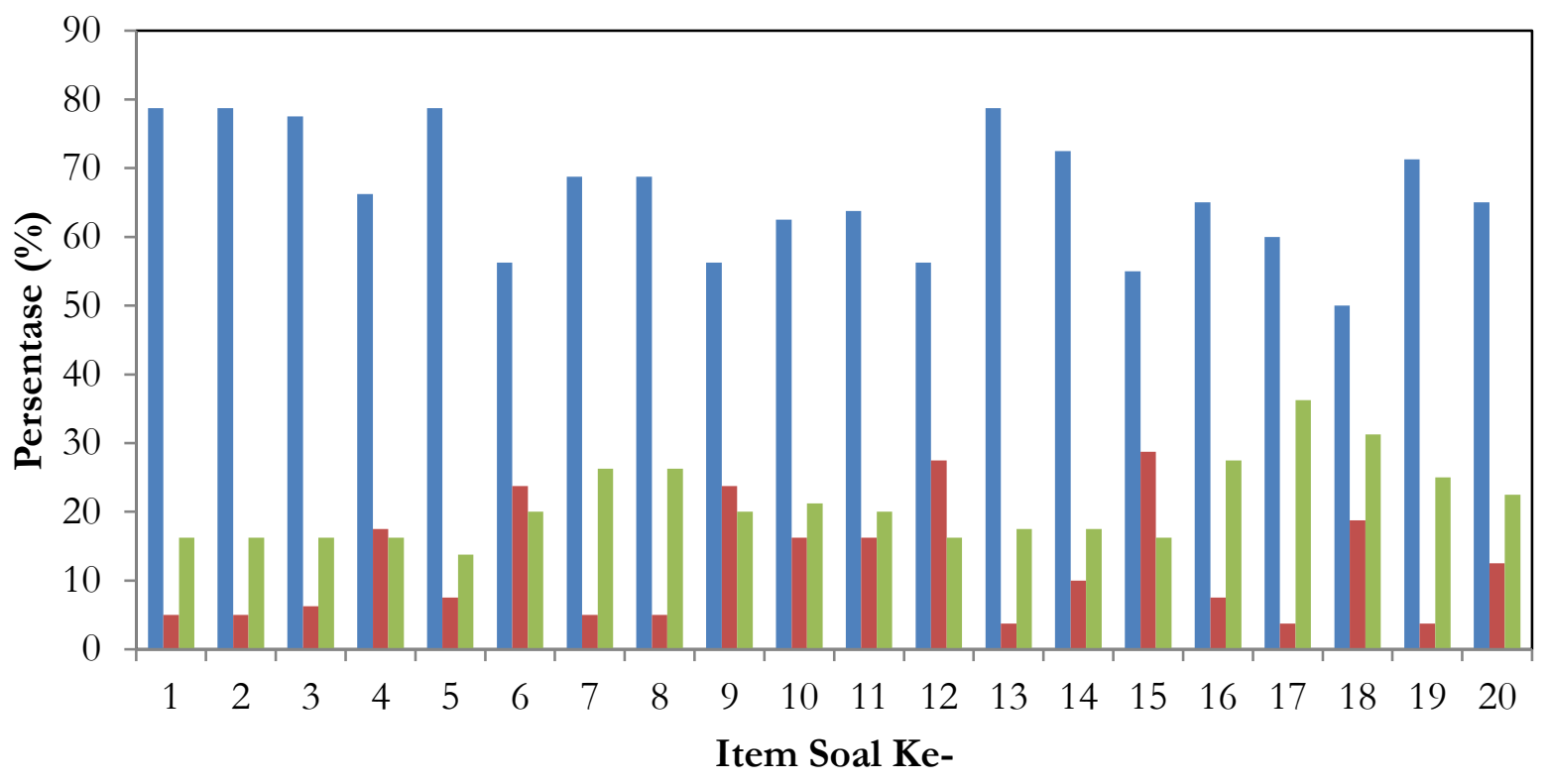

Miskonsepsi $\quad$ Paham Konsep $\quad$ Tidak Paham Konsep

Gambar 3. Grafik Persentasi Miskonsepsi, Paham Konsep dan Tidak Paham Konsep Siswa

Berdasarkan gambar 3, nampak bahwa persentase miskonsepsi siswa tertinggi untuk setiap nomor soal, terdapat pada nomor soal 1,2, 5 dan 13 yaitu 63 siswa dengan persentase $79 \%$ yaitu materi konsep definisi suhu, sifat termometrik benda, penentuan titik didih air, dan perbandingan benda dalam menerima kalor. Pada kasus penentuan titik didih air, siswa tidak mampu menjawab dengan benar tetapi alasan jawaban yang diberikan adalah benar. Sementara itu, persentase terendah 50\% diperoleh pada nomor soal 18 dengan jumlah 40 siswa. Sementara itu, persentase siswa yang tidak paham konsep masih lebih besar dibandingkan dengan siswa yang paham konsep terutama untuk item soal 1, 2, 3, 5, 7, 8, 10,11, 13, 14, 16, 17, 18, 19 dan 20. 
Dari hasil tersebut, maka dalam proses pembelajaran, guru harus menitiberatkan pengajaran pada siswa terkhusus untuk konsep-konsep tersebut. Konsep nomor 13 perbandingan benda dalam menerima kalor. Pada konsep ini sebagian besar siswa menjawab salah dengan nilai CRI yang tinggi. Siswa memahami bahwa ketika dua buah bola dengan diameter bola yang berbeda dimasukan kedalam air yang mendidih bersamaan maka kedua bola tersebut akan menerima kalor sama besar. Hal ini menunjukan bahwa siswa tidak memahami bahwa kalor yang dibutuhkan untuk merubah temperatur zat tertentu sebanding dengan massa zat tersebut yang berarti bahwa makin besar diameter bola maka volume akan semakin besar. Siswa mengalami miskonsepsi pada konsep kebergantungan ukuran benda dalam menerima suhu dan kalor. Hasil ini sejalan dengan hasil penelitian Sukarelawan dkk (2019) [17]; D. Gurcay dan E. Gulbas [18]; dan Eryilmaz [19].

Tabel 2. Jawaban Benar dan Salah Siswa tiap Item Soal

\begin{tabular}{|c|c|c|c|c|c|c|}
\hline $\begin{array}{l}\text { No. } \\
\text { Soal }\end{array}$ & Materi Suhu dan Kalor & $\begin{array}{l}\text { Jawaban } \\
\text { Benar }\end{array}$ & $\begin{array}{l}\text { Jawaban } \\
\text { Salah }\end{array}$ & $\begin{array}{l}\text { Persentase } \\
\text { Jawaban } \\
\text { Benar }(\%)\end{array}$ & $\begin{array}{c}\text { Alasan } \\
\text { Jawaban } \\
\text { Benar }(\%)\end{array}$ & $\begin{array}{c}\text { CRI } \\
\text { Tinggi } \\
(\%)\end{array}$ \\
\hline 1 & Definisi suhu & 10 & 70 & 12,5 & 8,75 & 83,75 \\
\hline 2 & $\begin{array}{l}\text { Identifikasi sifat termometrik pada } \\
\text { suatu benda }\end{array}$ & 19 & 61 & 23,75 & 22,5 & 82,5 \\
\hline 3 & Perbandingan suhu benda tertentu & 32 & 48 & 40 & 18,75 & 83,75 \\
\hline 4 & Satuan besaran pokok suhu & 28 & 52 & 35 & 46,25 & 83,75 \\
\hline 5 & Titik didih air & 31 & 49 & 38,75 & 21,25 & 86,25 \\
\hline 6 & $\begin{array}{l}\text { Konversi skala suhu skala Celcius } \\
\text { ke Kelvin }\end{array}$ & 33 & 47 & 41,25 & 35 & 75 \\
\hline 7 & $\begin{array}{l}\text { Hubungan antara skala Celcius } \\
\text { dan skala Fahreinheit }\end{array}$ & 34 & 46 & 42,5 & 16,25 & 73,75 \\
\hline 8 & $\begin{array}{l}\text { Persamaan kalibrasi termometer } \\
\text { pada skala Celcius dengan skala } \\
\text { sembarang }\end{array}$ & 18 & 62 & 22,5 & 22,5 & 73,75 \\
\hline 9 & Identifikasi zat padat & 31 & 49 & 38,75 & 38,75 & 81,25 \\
\hline 10 & $\begin{array}{l}\text { Identifikasi zat padat pada } \\
\text { kehidupan sehari-hari }\end{array}$ & 18 & 62 & 22,5 & 35 & 78,75 \\
\hline 11 & Definisi kalor & 35 & 45 & 43,75 & 53,75 & 80 \\
\hline 12 & Ciri-ciri proses perubahan kalor & 45 & 35 & 56,25 & 47,5 & 82,5 \\
\hline 13 & $\begin{array}{l}\text { Perbandingan suatu benda yang } \\
\text { menerima kalor }\end{array}$ & 30 & 50 & 37,5 & 25 & 81,25 \\
\hline 14 & Kejadian akibat pengaruh kalor & 19 & 61 & 23,75 & 28,75 & 87,5 \\
\hline 15 & Identifikasi proses menyerap kalor & 41 & 39 & 51,25 & 47,5 & 82,5 \\
\hline 16 & 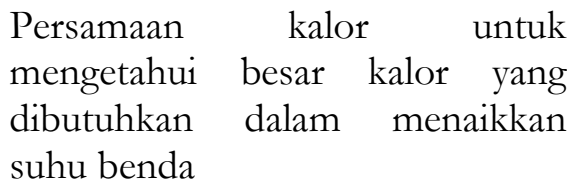 & 33 & 47 & 41,25 & 21,25 & 73,75 \\
\hline 17 & $\begin{array}{l}\text { Faktor yang mempengaruhi nilai } \\
\text { kapasitas kalor suatu zat }\end{array}$ & 15 & 65 & 18,75 & 17,5 & 65 \\
\hline 18 & Kalor jenis suatu benda & 33 & 47 & 41,25 & 33,75 & 71,25 \\
\hline 19 & $\begin{array}{l}\text { Perpindahan kalor secara } \\
\text { konduksi, konveksi, dan radiasi }\end{array}$ & 21 & 59 & 26,25 & 17,5 & 72,5 \\
\hline 20 & $\begin{array}{l}\text { Identifikasi perpindahan kalor } \\
\text { secara konduksi pada kehidupan } \\
\text { sehari-hari }\end{array}$ & 36 & 44 & 45 & 26,25 & 77,5 \\
\hline
\end{tabular}


Berdasarkan tabel 2, dapat kita lihat bahwa item soal tentang ciri-ciri proses perubahan kalor (soal nomor 12) memiliki persentase tertinggi jawaban benar siswa yaitu 56,25\%. Rata-rata alasan jawaban benar siswa diperoleh $29,19 \%$ lebih rendah dari alasan jawaban salah yaitu $70,81 \%$. Hal ini mengindikasikan bahwa siswa dalam memilih jawaban tanpa didasari oleh pemahaman terhadap konsep fisika yang ada pada setiap item soal. Alasan jawaban terendah terletak pada konsep definisi suhu.

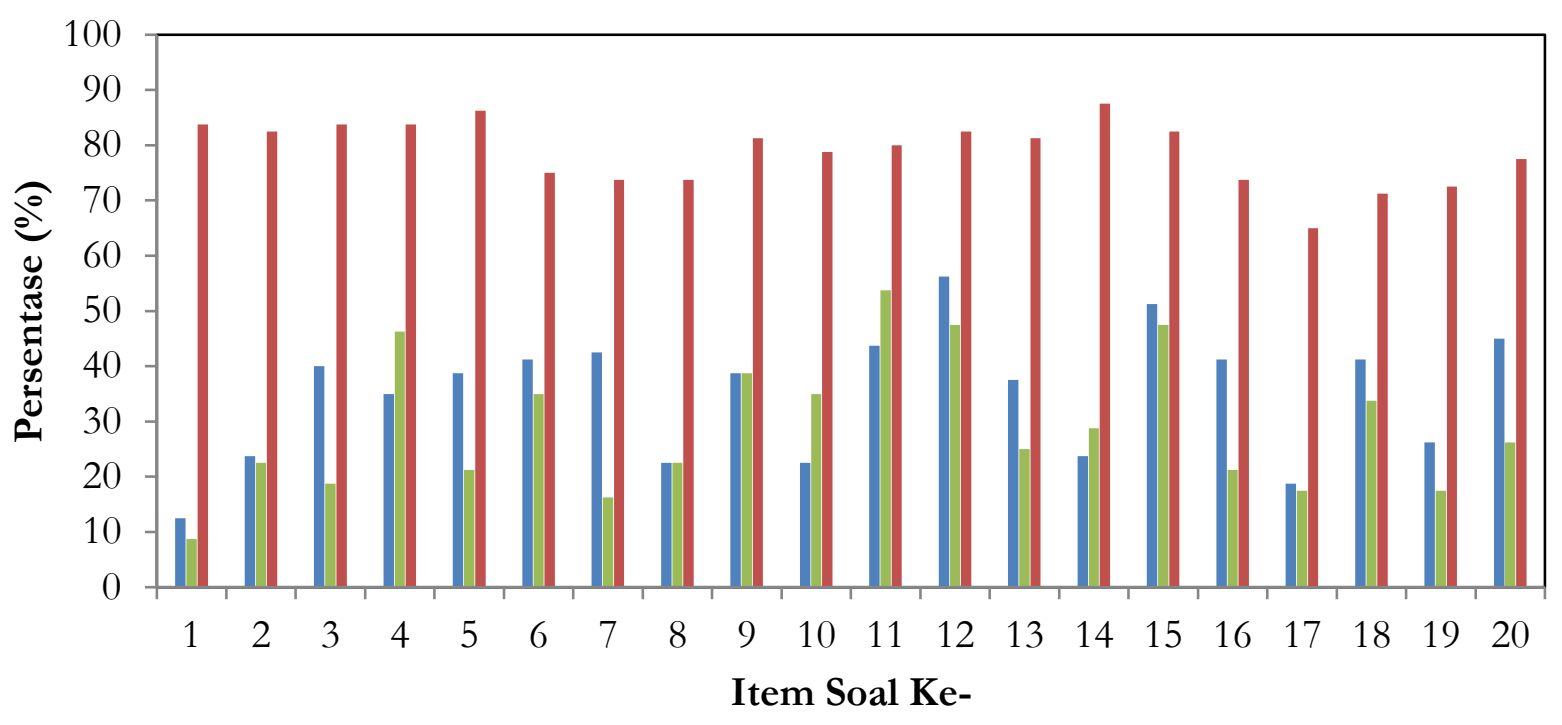

$$
\text { - Jawaban Benar Alasan Jawaban } \quad \text { CRI Tinggi }
$$

Gambar 4. Grafik Persentasi Jawaban Benar

Jawaban benar, alasan jawaban, dan CRI tinggi selanjutnya secara berturut-turut disebut sebagai level pertama, level kedua, dan level ketiga. Berdasarkan gambar 3, nampak bahwa rata-rata persentase jawaban benar lebih tinggi dari alasan jawaban. Hal ini karena pada kasus ini siswa hanya dituntut untuk memilih jawaban dari pilihan (soal pilihan ganda) yang diberikan tanpa memberikan alasan dari jawaban pilihan tersebut.

Tingkat persentase tertinggi jawaban benar untuk semua item soal adalah item nomor 12 yaitu $56,27 \%$. Hal ini menyiratkan bahwa item 12 merupakan persoalan yang relatif mudah dipahami oleh siswa. Sementara itu, persentase terendah adalah item 1 yaitu 12,5\%, yang mengindikasikan bahwa persoalan item 1 yaitu definisi suhu relatif sulit dipahami oleh siswa.

Tabel 3. Rata-rata Persentase Miskonsepsi Siswa pada materi suhu dan kalor

\begin{tabular}{ccc}
\hline No. & Materi & Rata-rata Persentasi Miskonsepsi $(\%)$ \\
\hline 1. & Suhu & 69,36 \\
2. & Kalor & 63,79 \\
\hline
\end{tabular}

Dari data tabel 3, persentase miskonsepsi tertinggi terjadi pada konsep Suhu dengan persentase miskonsepsi 69,36\%, sedangkan pada materi Kalor siswa mengalami miskonsepsi sebesar $63,79 \%$. Hasil yang sama juga dilaporkan oleh Sukarelawan dkk (2021), yang menunjukan bahwa rata-rata siswa mengalami miskonsepsi pada konsep suhu yaitu 57,6\% lebih besar dari pada konsep kalor yaitu 39,35\% [20].

\section{KESIMPULAN}

Berdasarkan hasil penelitian yang telah dilakukan, dapat disimpulkan bahwa siswa masih mengalami miskonsepsi tentang materi suhu dan kalor. Ini dapat dilihat dari hasil penelitian yang dilakukan dengan menggunakan instrument tes dalam bentuk pertanyaan three-tier multiple choice. Hasil analisis data menunjukan bahwa rata-rata persentase jawaban benar adalah 35,13\%, dan rata-rata 
persentase miskonsepsi siswa adalah 69\% untuk materi suhu dan 63,79\% untuk materi kalor. Item yang memiliki persentase tertinggi pada miskonsepsi adalah item-item dengan persentase terendah pada jawaban benar dan sebaliknya. Hal ini terjadi karena siswa sulit memahami materi konsep suhu dan kalor, dimana tingkat pemahaman siswa hanya berkisar 12,3\% serta tidak memiliki keyakinan yang tinggi atas pengetahuan yang mereka miliki.

\section{DAFTAR PUSTAKA}

[1] Mary B. Nakhleh, "Why some students don't learn chemistry: Chemical misconceptions," Journal of Chemical Education, vol. 69, no. 3, pp. 191-196, 1992.

[2] Almahdi Ali Alwan, "Misconception of heat and temperature Among physics students," in International Conference on Education and Educational Psychology (ICEEPSY 2010), 2011, pp. 600-614.

[3] Pauline Ross, Deidre Tronson, and J. Ritchie Raymond, "Modelling Photosythesis toIncrease Conceptual Understanding," Journal of Biological Education, vol. 40, no. 2, pp. 84-88, 2006.

[4] Paul Suparno, Miskonsepsi dan Perubahan Konsep dalam Pendidikan Fisika. Jakarta, Indonesia: Grasindo, 2005.

[5] Ali Eryilmaz, "Effects of Conceptual Assignments and Conceptual Change Discussions on Students' Misconceptions and Achievement Regarding Force and Motion," JOURNAL OF RESEARCH IN SCIENCE TEACHING, vol. 39, pp. 1001-1012, 2002.

[6] Lakshman S Myneni, N. Hari Narayan, Sanjay Rebello, Amy Rouinfar, and Sadhana Pumtambekar, "An Interactive and Intelligent Learning System for Physics Education," IEEE TRANSACTIONS ON LEARNING TECHNOLOGIES, vol. 6, no. 3, pp. 228-239, JULYSEPTEMBER 2013.

[7] Ida Kaniawati et al., "Analyzing students' misconceptions about Newton's laws through FourTier Newtonian Test (FTNT)," Journal of TURKISH SCIENCE EDUCATION, vol. 16, no. 1, pp. 110-112, March 2019.

[8] Masril, "Pengembangan Model Pembelajaran Fisika SMA Berbasis Graphic Organizer Melalui Belajar Kooperatif Tipe STAD," Jurnal Penelitian Pembelajaran Fisika, vol. 1, no. 1, pp. 1-7, Februari 2012.

[9] Hasim Wahid and Nasrul Ihsan, "IDENTIFIKASI MISKONSEPSI MATERI USAHA, GAYA DAN ENERGI DENGAN MENGGUNAKAN CRI (CERTAINTY OF RESPONSE INDEX) PADA SISWA KELAS VIII SMPN 1 MALANGKE BARAT," Jurnal Sains dan Pendidikan Fisika, vol. 7, no. 1, pp. 25-37, 2011.

[10] Sule Bayraktar, "Misconceptions of Turkish Pre-Service Teachers about Force and Motion," International Journal of Science and Mathematics Education, vol. 7, pp. 273-291, 2009.

[11] Hans-Dieter Barke, Al Hazari, and Sileshi Yitbarek, Misconceptions in Chemistry, 1st ed. Berlin: Springer-Verlag Berlin Heidelberg, 2009.

[12] Pei-Shan Chan, Huan-Chueh Wu Chien Chou, "Using a two-tier test to assess students' understanding and alternative conceptions of cyber copyright laws," British Journal of Educational Technology, vol. 38, no. 6, pp. 1072-1084, 2007. 
[13] Harika Ozge Arslan, Ceyhan Cigdemoglu, and Christine Moseley, "A Three-Tier Diagnostic Test to Assess Pre-Service Teachers' Misconceptions about Global Warming, Greenhouse Effect, Ozone Layer Depletion, and Acid Rain," International Journal of Science Education, vol. 34, no. 11, pp. 1667-1686, May 2012.

[14] Haki Pesman and Ali Eryilmaz, "Development of a Three-Tier Test to Assess Misconceptions About Simple Electric Circuits," The Journal of Educational Research, vol. 103, no. 3, pp. 208-222, 2010.

[15] Zubeyde Demet Kirbulut and Omer Geban, "Using Three-Tier Diagnostic Test to Assess Students' Misconceptions of States of Matter," Eurasia Journal of Mathematics, Science and Technology Education, vol. 10, no. 5, pp. 509-521, 2014.

[16] Nursarifa Zahra, Kamaluddin Kamaluddin, and Muslimin Muslimin, "IDENTIFIKASI MISKONSEPSI FISIKA PADA SISWA SMAN DI KOTA PALU," Jurnal Pendidikan Fisika Tadulako Online (JPFT), vol. 3, no. 3, pp. 61-66, 2015.

[17] Moh. Irma Sukarelawan, Jumadi, and Nurulhuda Abdul Rahman, "An Analysis of Graduate Students' Conceptual Understanding in Heat and Temperature (H\&T) Using Three-Tier Diagnostic Test ," Indonesian Review of Physics, vol. 2, no. 1, pp. 9 - 14, 2019.

[18] D. Gurcay and E. Gulbas, "Development of Three-Tier Heat, Temperature and Internal Energy Diagnostic Test," Res. Sci. Technol. Educ., vol. 33, no. 2, pp. 197 - 217, 2015.

[19] A. Eryilmaz, "Development and Application of ThreeTier Heat and Temperature Test: Sample of Bachelor and Graduate Students," Eurasian J. Educ. Res., no. 40, pp. 53 - 76, 2010.

[20] Moh Irma Sukarelawan et al., "Four-Tier Heat and Temperature Diagnostic Test (4T-HTDT) to Identify Student Misconceptions," JIPFRI (Jurnal Inovasi Pendidikan Fisika dan Riset Ilmiah), vol. 5, no. 1, pp. 1 - 8, May 2021.

[21] H.-E. Chu, D. F. Treagust, S. Yeo, and M. Zadnik, "Evaluation of Students' Understanding of Thermal Concepts in Everyday Contexts," Int. J. Sci. Educ, vol. 34, no. 10, pp. 1509 - 1534., 2012. 